\title{
STUDENTS' PERCEPTIONS OF M-READER
}

\author{
Abouzar Rajabpour \\ (abouzar@squ.edu.om) \\ Sultan Qaboos University \\ I Khoud Muscat 123 Street, Oman
}

\begin{abstract}
Many universities in the Middle East, for instance, Shiraz University in Iran and Sultan Qaboos University in Oman have been running M-reader, a free Internet site which helps educational institutions to manage extensive reading (ER), as a way of including Extensive Reading in ELT classes for years. In spite of few attempts to evaluate this online tool based on different aspects, no studies have focused on students' ideas toward the pros and cons of M-reader and how it can be improved. Hence, using a large sample, the present study sheds some light on potential advantages and drawbacks of M-reader and, ultimately, presents students' comments on how to idealize this popular Extensive Reading tool. A mixed-method design was used in data collection and data analysis. The study shows that M-reader is a popular online platform among students despite some potential drawbacks.
\end{abstract}

Keywords: ELT, extensive reading, M-reader

DOI: http://dx.doi.org/10.15639/teflinjournal.v31i2/277-301

Extensive reading (ER) is considered essential for English as a foreign language (EFL) learners since it benefits the language learners in several ways including improved reading fluency (Huffman, 2014; McLean \& Rouault, 2017; Nakanishi, 2015), vocabulary acquisition (Al Damen, 2018; Suk, 2016; Webb \& Chang, 2015) and better writing skills (Mermelstein, 2015; Park, 2016). Consequently, there has been a swift expansion in the implementation of ER in foreign language programs (Brown, 2012). Inevitably, some teachers consider judging students on how well they have completed their Extensive Reading pedagogically challenging (Brown, 2012; Campbell \& Weatherford, 2013; Robb \& Kano, 2013). Additionally, some expressed administrative concerns about having adequate time to design ER programs or having enough time in the class (Day \& Bamford, 1998; Robb, 2009), specifically when 
unmotivated Arab EFL learners are in the class (Al Damen, 2018). As a reflection, M-Reader was designed to be an aid to academic institutions to implement an ER program. M-reader is a free Internet site which is designed to enable educational centers to manage ER effectively. It helps teachers to verify whether or not students have read and understood graded reader books. After reading the books, students take online quizzes to evaluate their understanding of story plots and characters. M-reader was designed in Kyoto Sangyo University and is now used by educational institutions in 26 countries.

Although some previous studies (McBride \& Milliner, 2018; Robb, 2009) have shown that students have a positive attitude toward M-reader, there is a noticeable absence of large-scale studies which might yield more generalizable outcomes. Hence, the present study investigates students' perception of Mreader using a large sample of students who had an additional ER activity as a part of their English course in the Foundation Programme at Sultan Qaboos University in Oman. On account of exploiting quantitative and qualitative data, the study summarizes students' general idea about M-reader and subsequently, reflects students' comments on how to upgrade this online tool. The current survey would serve as a cornerstone for further studies considering students' perceptions of various ER methods used currently. It may also help the stakeholders and curriculum developers to refine their ideas about how to help students with their reading. Furthermore, the findings can give the teachers more insights into how their students really think about M-reader. It may also assist M-reader designers in determining any potential problems in this platform.

Due to the huge gap in the literature concerning students' perceptions of the M-reader, specifically in the Gulf, the present study tries to answer the following questions:

1. How do Omani students perceive the benefits of the M-reader in their Foundation Programme at SQU?

2. What do students like the most about M-reader?

3. From students' perspectives, what drawbacks does M-reader have?

4. What do students suggest to improve M-reader as an ER tool?

\section{Reading among Arabs and in Oman}

Many scholars believe that Arabs lack the culture of reading both in English and Arabic (Al-Mahrooqi \& Denman, 2016; Bell 2001). This cultural 
gap can be generally attributed to several factors like "late arrival of formal education systems, lack of libraries, a strong oral culture, Arabic diglossic nature, high rates of adult illiteracy, social instability, and traditional teaching methods" (Al-Mahrooqi \& Denman, 2016, p. 6).

According to Al-Musalli (2014), Omanis do not appreciate reading either in English or Arabic due to several factors such as insufficient number of libraries, a high number of illiterate adults and parents, and the abundant homework done at home. Al-Mahrooqi (2012) states that Omani learners do not have enough motivation to do ER because they assume that all kinds of reading are for academic study. Al Yaaqubi and Al-Mahrooqi (2013) conducted a study on 66 Omani university students majoring in English. They investigated how reading for pleasure affected personal, emotional, social, and language learning lives of these students. They utilized a questionnaire with quantitative and qualitative sections. They found that $36 \%$ of participants read only an average of one book and a half every semester. The more amazing finding was that about $20 \%$ of them did not read any books during the same period of time.

\section{Extensive Reading}

Extensive reading exposes learners to a plenty of pleasurable material in their linguistic level (Grabe \& Stoller, 2002). The common purpose of most ER programs is to have learners read large quantities of self-selected, simplified texts in a way that promotes the joy of reading in a foreign language (Day \& Bamford, 1998; Renandya, 2007).

In addition to the numerous studies on reading skills and strategies, many researchers have also focused on the effectiveness of ER including studies on adult learners (Greenberg et al., 2006; Renandya et al., 1999), vocabulary building (Horst, 2005; Kweon \& Kim, 2008; Modirkhamene \& Gowrki, 2011; Pigada \& Schmitt, 2006; Tran, 2006), reading speed and comprehension (Bell, 2001; He, 2014; Taguchi et al., 2004). There are also a great number of studies emphasizing students' positive attitudes (Camiciottoli, 2001; Johnson, 2012; Shen, 2008; Stoeckel et al., 2012) and motivations (Apple, 2005; Mason \& Krashen, 1997; Takase, 2007) towards the ER.

Day and Bamford (2002, pp. 137-141) introduced 10 key components of a successful ER program and encouraged teachers to use them. However, several ER scholars (e.g., Macalister, 2015; Waring \& McLean, 2015) challenged these 
10 principles and criticized some of them in terms of contextual and curricular constraints. Furthermore, some researchers tried to replace one of these principles (principle 6) including accountability measures to make students take ER more seriously. This principle was formerly 'Reading is a reward in itself.'

1. Ease of reading material.

2. Availability of a variety of reading material on a wide range of topics.

3. Learners' choice in what they want to read.

4. Reading as much as possible.

5. Reading for pleasure, information and general understanding.

6. Reading is monitored and assessed. (Ng et al., 2019).

7. Read quickly and not slowly.

8. Reading silently and individually.

9. Teachers guide students.

10.Teacher is a reading model.

Many empirical studies have investigated the efficacy of ER as a substitute to other EFL reading activities in the classroom using a control group. (Bell, 2001; Lai, 1993; Robb \& Sheu, 2003; Susser, 1989; Tanaka \& Stapleton, 2007). Nevertheless, all of them suffered from bias or ethical issues. In addition, there are some practical challenges teachers face when implementing an ER component in their language class. Those challenges included how to identify whether or not students are reading effectively (Brown, 2012; Campbell \& Weatherford, 2013; Robb, 2015; Robb \& Kano, 2013; Stewart, 2014), how to provide adequate reading support for students (Day \& Bamford, 1998; Robb, 2009), and how to motivate students to read in large quantities (Brierley, 2009; Mori, 2015; Robb, 2002).

Robb \& Kano (2013) concluded that ER could be effectively implemented if there are reliable means to hold students accountable for their work without increasing the workload of teachers. Hence, they introduced MoodleReader (M-Reader) as a way of satisfying these needs. They incorporated this plug-in module to hold students accountable for their reading outside the classroom. Comparing 2008 cohort who did no reading outside the classroom and 2009 cohort students who had to read outside the classroom, they concluded that implementing ER resulted in highly significant gains. 
Rajabpour, Students' Perception of M-reader 281

\section{ER Implementation}

The way ER is incorporated into any academic program is a mainly context-specific decision and is dependent upon several factors including facilities available, space, time, material, etc. Different educational centers make use of diverse designs in implementing ER using various material. For instance, in line with the Indonesian government's National Literacy Movement, the Indonesian Extensive Reading Association introduced three steps for setting up an ER program in Indonesian schools (Anandari \& Iswandari, 2019). Schools had to plan their libraries, set them up and categorize the books based on levels and finally, introduce what extensive reading is and how it is going to work to students.

Researchers also utilize different approaches in the implantation of ER when they are conducting studies. Milliner (2017) ran a study on 19 university students who read graded readers on their smartphones for one academic year. $\mathrm{He}$ adapted core and variable dimensions from Waring and McLean (2015). He reported an increase in the TOEIC scores of the majority of the students after the treatment. Low number of participants and no comparison with a control group are among the limitations of his study.

In another study, Boutorwick, Macalister and Elgort (2019) used short story books to compare an ER-only group with and ER-plus group. The second group received and extra 'Say-it' activity which was a post-reading smallgroup discussion task. They found out facilitative effects of both ER approaches on students' vocabulary knowledge. Their study was limited in several aspects. The students were not engaged that much, some intervening variables were not controlled and there were no post-tests measuring the effects of the treatments.

Aulia (2019) conducted a study where the participants were asked to make a reading $\log$ as a summary of their ER activities during 16 weeks. Students chose the reading material from five literary genres from various sources outside the classroom, selected the difficulty level of the material and presented their progress in the form of a $\log$ in the class. She concluded that students have benefits in promoting ER activity through making reading logs. However, she noticed that although students have freedom of choice, it was difficult for students to manage their limited free time.

Day (2015) suggested that current practices of supervised (or instructed) ER will continue. He predicted that independent (or non-instructed) ER might 
also take place. Furthermore, Day (2015) stated that there would be greater use of Internet ER tools such as Moodle Reader Module, and Internet would play a very important role in providing reading materials. This increasing trend in the prominence of the Internet has been reflected in the unprecedented implementation of M-Reader module in various educational centers around the world.

\section{M-reader}

M-reader (available at https://mreader.org) is a browser-based version of the Moodle Reader that was first developed in Kyoto Sangyo University in Japan. It is supported by different graded reader publishers, and it seems to be convenient for administrators, teachers, and students to use. M-reader helps both teachers and students manage ER more effectively (McBride \& Milliner, 2018).

Different studies have investigated the effectiveness of M-reader as a way to support ER. Allan (2014) claims that the M-reader is free, easy to access, motivational and can be incorporated into a language learning curriculum. $\mathrm{He}$ agreed that M-reader is a means of tracking student's gradual growth in achieving their ER goal as the semester passes. However, he did not give any specific details of the study in his article. Moreover, Al Damen (2018) found that M-reader is effective in stimulating students to do ER, has a positive influence on the students' attitudes towards reading and helps enhance autonomous learning among them. Nevertheless, he mentioned several limitations to his study, such as the lack of expertise among some teachers, the limited number of books and the inadequate number of participants.

Few studies have investigated students' perceptions or attitudes toward Mreader after they have reached their ER goals. Cheetham et al. (2016) focused on the attitudes of 36 EFL students. In their study, students who read 100,000 words with M-Reader quizzes entered a reading contest called the 'M-Reader Challenge', a competition that promotes ER by rewarding students who reach an elevated reading goal. They evaluated the attitudes of the students who successfully completed this challenge in M-reader using a questionnaire and semi-structured interviews. The results from this study suggested that reading graded readers in general enhanced intrinsic motivation among a majority of the participants. In spite of their exceptional work, the study lacks a good participant sample. 
McBride and Milliner (2018) reported students' perceptions of M-reader during a pilot program for M-reader in English as a Lingua Franca (ELF) classes at a private university in Tokyo. Participants of the study had positive perceptions of the M-reader system because of its convenience of use, records of their reading progress and facilitating work with graded reader books. Nonetheless, they only used quantitative tools to measure what students think of M-reader.

Bieri (2015) conducted a study to address how M-reader was perceived by the students and instructor-researcher in three reading classes at a Japanese university to see whether M-reader resulted in more accurate and less timeconsuming assessment. He collected qualitative data from 90 first-year university students, none of whom were studying English as their major. $\mathrm{He}$ concluded that students seemed to have an overall positive view towards Mreader and M-reader was a positively motivating factor for most students. Furthermore, he pointed out several weaknesses of M-reader from students' point of view, that is, possible cheating, lack of quizzes for some books, quiz difficulty, and time limitations on taking quizzes. However, his work lacked a sufficient number of participants and hence, is not generalizable to other contexts.

It is clear that M-reader is a useful tool to develop ER in students, and that Extensive Reading has a great potential in developing learners' reading proficiency including reading fluency and improved reading habits. In spite of the many studies on M-reader in different parts of the world, no studies have focused on students' ideas toward the pros and cons of M-reader and how it can be improved. To address the gaps in the previous studies and to check whether or not M-reader is working from students' view, the researcher attempts to investigate Omani students' actual perceptions of M-reader at the Foundation Programme at SQU.

\section{METHOD}

\section{M-reader at SQU Foundation Programme}

At SQU, students read about 8 books in a 14-week semester where the ideal is a book per week. Using M-reader, students can track how many words they read, which books they read, how their levels move up as they read more 
and how they are doing compared to their classmates, SQU students, and students around the world. Students easily log in using their username and password. Table 1 summarizes the word count level for each course in the Foundation Programme. FPEL stands for Foundation Programme for English Language, LANC is the Language for Credit courses and $\mathrm{S} / \mathrm{H}$ show if the course is for either science students or humanities.

Table 1. M-reader Word Goals for Each Course at SQU

\begin{tabular}{|c|c|c|c|}
\hline Course & Word goal & Course & Word goal \\
\hline FPEL 0120 & 15000 & FPEL 0340 & 35000 \\
\hline LANC 1026 & 20000 & FPES/H 0450 & 50000 \\
\hline LANC 1006 & 25000 & FPES/H 0560 & 60000 \\
\hline FPEL 0230 & 25000 & FPES/H 0603 & 60000 \\
\hline
\end{tabular}

\section{Study Design and Instrumentation}

The present study used a mixed-method design to provide a better understanding of the research problems and questions than either method by itself (Geluykens, 2008). In a multiple method design, quantitative and qualitative research methods are combined rather than integrated. This results in "a very powerful mix" (Miles \& Huberman, 1994, p. 42) and "a complex picture of social phenomenon" (Greene \& Caracelli, 1997, p. 7). This study implements the following steps. Firstly, quantitative data were collected through a 10-item questionnaire. The questionnaire was adapted and adjusted from the study done by Cheetham et al. (2016). The Japanese translation in the original questionnaire was changed into Arabic. Besides, some questionnaire items were ignored due to non-applicability to the context. This questionnaire was selected because it considers the multi-faceted nature of motivation. The study was also highly reliable. It attempted to measure the participants' perceptions in terms of learners' perceived English ability and future usage. The questionnaire seemed to be one of the few available questionnaires in the literature considering attitudes towards $\mathrm{M}$-reader. To supplement the results with qualitative data, three open-ended questions were added as a comment section. 
Rajabpour, Students' Perception of M-reader 285

\section{Participants}

The participants of the study are students of the Foundation Program at SQU. As shown in Table 1, these students are assigned a word count to be achieved by the end of the semester based on their levels. Since a larger sample size provides more precise mean values, identifies outliers and gives a smaller margin of error (Creswell \& Clark, 2018), all students taking M-reader quizzes as a part of their course at the Foundation Programme in Fall 2019 were given the opportunity to share their ideas. Unexpectedly, 744 students completed the questionnaire, about half of them answered the first and second open-ended questions and around 400 respondents shared their ideas on the third question by giving comments on how to improve M-reader.

\section{Data Collection and Analysis}

After reaching their deadline for M-reader at the final week of the classes, all the participants of the study were sent a mail through the university mailbox. After asking for their consent for participating in the study, they responded to each statement in the questionnaire on a Likert scale consisting of Strongly disagree, Disagree, Agree and Strongly agree. These questions provided the quantitative data of the results. The results were reported in the forms of descriptive and inferential statistics. Eventually, the quantitative data were entered into SPSS for statistical evaluations.

Bartlett's Test of Sphericity and Kaiser-Meyer-Olkin measure of sampling adequacy (KMO) were performed. The result showed that Bartlett's test of Sphericity was significant ( $\mathrm{p}<05)$, and KMO was .92 which was quite acceptable (Gravetter \&Wallnau, 2008). These results revealed the appropriateness for proceeding with a factor analysis.

To see whether items of the questionnaire are measuring the same trait or factor and to ensure that the information among factors would not overlap, principal components analysis (PCA) with varimax rotation of orthogonal rotation was run for the factor analysis (Howell, 2011). Accordingly, one of the items of the questionnaire regarding the challenge in M-reader quizzes was eliminated for it showed no significant correlation with any other item in the questionnaire (Yamini \& Rahimi, 2007). The factor loading for all of the remaining items were more than .5 and none had to be excluded further (Hair et al., 2010). The eigenvalue for the only extracted component was greater than 4 which explained $57.6 \%$ of variance, showing that the validity of the scale was 
sufficient. The Cronbach's alpha of the items was .894, indicating good reliability.

Furthermore, to find out students' comments on M-reader, the participants were asked three open-ended questions about the positives and negatives of $\mathrm{M}$ reader at the bottom of the questionnaire. The responses to the two open-ended questions were analyzed further for the existing common themes in participants' ideas. These themes or codes were categorized based on word repetition technique (Ryan \& Bernard, 2003). Finally, the results were presented in form of graphs to see what common idea or ideas the participants have regarding the strengths and weaknesses of M-reader.

\section{FINDINGS AND DISCUSSION}

\section{Findings}

The purpose of this study was to investigate how students actually think about M-reader as a way of implementing ER in the Foundation Programme. According to the descriptive statistics in Table 2, it could be argued that Mreader is generally favourable to most of the students in different aspects, particularly in terms of improved English language skills. The mean for most of the items were above 6 while the mode for all of them was Agree.

Table 2. Descriptive Statistics of How Students Perceived M-reader

\begin{tabular}{|c|c|c|c|c|c|c|}
\hline Item & $\frac{2}{8}$ & $\frac{2}{0}$ & 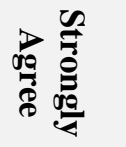 & $\underset{8}{\stackrel{8}{8}}$ & 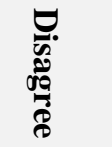 & 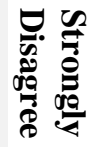 \\
\hline $\begin{array}{l}\text { 1. I have enjoyed reading Graded } \\
\text { books on M-reader. }\end{array}$ & .87 & Agree & $26.5 \%$ & $57.1 \%$ & $9.5 \%$ & $6.9 \%$ \\
\hline $\begin{array}{l}\text { 2. M-reader has helped me } \\
\text { improve my overall English } \\
\text { language skills. }\end{array}$ & .77 & Agree & $19.5 \%$ & $62.1 \%$ & $12.9 \%$ & $5.5 \%$ \\
\hline $\begin{array}{l}\text { 3. My reading speed has } \\
\text { improved after finishing M- } \\
\text { reader. }\end{array}$ & .77 & Agree & $20 \%$ & $61 \%$ & $13.6 \%$ & $5.2 \%$ \\
\hline $\begin{array}{l}\text { 4. My vocabulary has increased } \\
\text { after finishing M-reader. }\end{array}$ & .69 & Agree & $17.5 \%$ & $60.5 \%$ & $17.2 \%$ & $4.8 \%$ \\
\hline
\end{tabular}


Rajabpour, Students' Perception of M-reader 287

\begin{tabular}{|c|c|c|c|c|c|c|}
\hline Item & $\stackrel{3}{3}$ & $\frac{2}{0}$ & 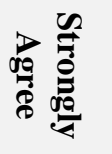 & $\underset{8}{8}$ & 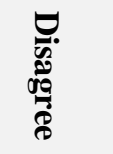 & 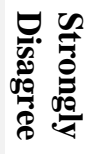 \\
\hline $\begin{array}{l}\text { 5. My reading comprehension has } \\
\text { improved because of M-reader. }\end{array}$ & .57 & Agree & $15.9 \%$ & $57.4 \%$ & $21 \%$ & $5.8 \%$ \\
\hline $\begin{array}{l}\text { 6. I think reading for pleasure in } \\
\text { English is important. }\end{array}$ & 1 & Agree & $36.4 \%$ & $47.8 \%$ & $11.2 \%$ & $4.6 \%$ \\
\hline $\begin{array}{l}\text { 7. I think an important reading } \\
\text { goal is achieved when I pass an } \\
\text { M-reader quiz. }\end{array}$ & .64 & Agree & $18 \%$ & $58.1 \%$ & $17.6 \%$ & $6.3 \%$ \\
\hline $\begin{array}{l}\text { 8. M-reader has encouraged me } \\
\text { to read more English books. }\end{array}$ & .48 & Agree & $22.6 \%$ & $45 \%$ & $23 \%$ & $9.4 \%$ \\
\hline
\end{tabular}

Considering the enjoyment of reading Graded Books, it was found that almost $80 \%$ of the students have enjoyed reading this type of books. It seems to be playing a big role in attracting students toward reading more and more. The results of the analysis also show that nearly $70 \%$ of the participants believe that M-reader has helped them in improving their overall English language skills. The students generally acknowledge M-reader as a means of improving reading speed, vocabulary range and reading comprehension. They expressed their positive attitude toward the role of M-reader in each of these skills, with the percentage of $81 \%, 77.5 \%$ and $73 \%$, respectively. The participants also believe that when they pass an M-reader quiz, one of their significant reading goals is achieved. As the final item in the questionnaire, the students reflected on the role of M-reader in raising their motivation in reading further English books. This item had the lowest mean among all of the entries with $67 \%$ of agreement from the respondents.

To answer the three remaining research questions where students expressed their comments in the form of short answers, the qualitative data were explored manually following the word repetition technique. Table 3 and Table 4 illustrate students' ideas sorted according to their frequencies.

Table 3. Students' Views on M-reader's Pros and Cons

\begin{tabular}{lclc}
\hline $\begin{array}{l}\text { What did you like the } \\
\text { most about M-reader? }\end{array}$ & Frequency & $\begin{array}{l}\text { What drawbacks does } \\
\text { M-reader have? }\end{array}$ & Frequency \\
\hline Stories / Topics & 101 & Nothing & 142 \\
\hline Nothing & 59 & Difficult tests/Questions & 52 \\
\hline
\end{tabular}


288 TEFLIN Journal, Volume 31, Number 2, July 2020

\begin{tabular}{lclc}
\hline $\begin{array}{l}\text { What did you like the } \\
\text { most about M-reader? }\end{array}$ & Frequency & $\begin{array}{l}\text { What drawbacks does } \\
\text { M-reader have? }\end{array}$ & Frequency \\
\hline Vocabulary & 53 & Books & 46 \\
\hline Reading & 44 & M-reader features & 42 \\
\hline Variety of books / levels & 41 & Difficult words & 29 \\
\hline Tests / Questions & 26 & Time & 29 \\
\hline Ease of use & 19 & Word limit / level & 12 \\
\hline Motivation & 18 & Whole system & 11 \\
\hline Competition / Challenge & 13 & $\begin{array}{l}\text { Going to library / } \\
\text { Borrowing books }\end{array}$ & 8 \\
\hline Miscellaneous & 15 & Miscellaneous & 6 \\
\hline Total & $\mathbf{3 4 8}$ & Total & $\mathbf{3 8 7}$ \\
\hline
\end{tabular}

Table 3 reflects what students perceived of M-reader and what advantages and disadvantages they figured out after using this online tool. It could be argued that 100 students were mainly interested in the stories or topics of the books, while the other 41 liked the variety of books and levels. Around 60 students did not notice any specific advantages in M-reader. Fifty-three and 44 of them mentioned improvement on their vocabulary range and reading skill as the main benefit of M-reader, respectively. Tests, ease, motivation and challenge were the remaining salient factors spotted by students as a positive characteristic of M-reader. On the other hand, as far as the drawbacks of Mreader are concerned, 142 students did not find any specific problems in this program. The first issue in M-reader in students' idea was the tests or questions. They believed that the questions in M-reader tests are tough for them. Forty-six participants had problems with the books, especially with the low variety and the limited number of books available for students in the library. Another 42 had problems with the rules and limitations of M-reader such as waiting 24 hours for the next quiz or having only one book at a time. Difficult vocabulary was the main concern for around 30 students. Another 30 faced some issues with the time limit in the tests. The remaining mentioned the word limit and going to the library as the problems they encountered while completing their task. Only 11 participants were not happy with the whole system. It can be interpreted that books play a significant role in the popularity of this online program. While many students see the books as the salient strength of M-reader, many of them complained about the variety and availability of the books in the library. Although some students think that the 
test features are an advantage of M-reader, some others think that the questions in the tests are troublesome and they do not have enough time to complete them. It seems that the students' comments are directly associated with their overall attitude toward M-reader.

Ultimately, students' feedbacks to the last open-ended question were scrutinized to see what suggestions that the students propose for the betterment of M-reader. Table 4 summarizes the findings from the most to the least frequent comments.

Table 4. How to Improve M-reader

\begin{tabular}{llc}
\hline Comment & & Frequency \\
\hline Add new books & & 59 \\
\hline No improvement needed & & 38 \\
\hline 'I don't know' & Simpler Q. & 33 \\
\cline { 2 - 3 } Test & Harder Q. & 18 \\
\cline { 2 - 3 } & Time & 8 \\
\cline { 2 - 3 } & Q. Diversity & 6 \\
\hline Online & & 14 \\
\hline Time limit & & 23 \\
\hline \multirow{2}{*}{ More encouragement } & Rewards & 17 \\
\cline { 2 - 3 } & Competitions & 6 \\
\hline Remove levels & & 6 \\
\hline More than 1 book & & 11 \\
\hline & Stories $\rightarrow$ Books & 6 \\
\cline { 2 - 3 } & Bigger Library & 5 \\
\cline { 2 - 3 } Miscellaneous & Movies/CD & 4 \\
\cline { 2 - 3 } & Vocab/Grammar Q. & 5 \\
\cline { 2 - 3 } & App & 5 \\
\hline
\end{tabular}

Not surprisingly, books were the first element where students seek for improvement. They offered adding new and various books. Around 40 students think that M-reader needs no advancement while another 30 had no ideas on how to improve M-reader saying 'I don't know'. Forty-six comments targeted the tests where students asked for simplicity, difficulty, variety and more time for the questions. Twenty-three participants suggested availing the books online, 17 wrote about removing time limits, 12 encouraged giving out more awards and challenges, 11 asked for removing the levels and 10 of them 
offered reading more books at once. Changing stories to 'real' books, making the library bigger, introducing CDs and movies along with the stories, adding vocabulary or grammar questions and introducing M-reader application were the low-frequent opinions shared by students.

\section{Discussion}

\section{Graded Books}

The first item in the questionnaire targeted the Graded Books which are utilized in M-reader. The findings clearly indicate the students' positive attitude toward these series. This part of finding is similar to that of Robb (2015), Cheetham et al. (2016), and McBride and Milliner (2018) where they reported that the students like the Graded Books. The findings are also consistent with that of Krashen et al. (2018) where they stated that "input must be at least interesting so that acquirers will pay it attention" (Krashen et al., 2018 , p. 2). This could be because the students read the books completely and have a complete experience in it. The results suggest that the books used in Mreader are perceived positively by students. It could be claimed that these books achieve their assigned goal in fostering ER among the students because they seem to be interesting to the students. This generally positive attitude toward graded readers show evidence of intrinsic motivation and is in line with Eccles' expectancy value theory (Wigfield, 1994; Wigfield \& Eccles, 2000). The findings also comply with the elements of Day and Bamford's "Ten Principles of ER."

However, as illustrated in Table 4, many students suggest adding new books to the existing ones. That students choose what they want to read is really essential to any ER program (Cheetham, et al., 2016) because it motivates students to read as much as possible (McBride \& Milliner, 2018), keeping with the principles from Day and Bamford (2002). Consequently, students should not feel limited when it comes to selecting books. The limited number of books was also reported by Al Damen (2018). Relevant officials need to reconsider their bank of books in a more meticulous way. The findings clearly indicate the fact that despite the books are favourable among the students, there should be a consistent freshening-up system where new books are added regularly to keep the students motivated. 
Rajabpour, Students' Perception of M-reader 291

\section{Overall English Proficiency}

The students strongly believe that M-reader influences their overall English language skill. The findings are in line with much of the little available literature on the topic (Cheetham et al, 2016; Robb, 2015). This could be an indication of the positive impact of M-reader on students' general English proficiency. One possible reason might be the autonomous nature of M-reader where students complete their task whenever they feel like doing it. It is also possible that some students may have been evaluating their language skills rather than their learning progress in their Likert scale responses. To conclude, students' point of view is that M-reader is assisting them in enhancing their English language skills in general. Although it is difficult for students to assess all their skills at once, it could be speculatively stated that students believe that M-reader has changed their English proficiency level in a positive way.

\section{Reading Speed, Vocabulary Range and Reading Comprehension}

Items 3, 4 and 5 of the questionnaire considered three aspects which are more closely related to reading skill, that is, in terms of reading speed, vocabulary range, and reading comprehension. Firstly, a big portion of students expressed that M-reader has incremented their reading speed. Cheetham et al. (2016) say that reading speed is more tangible than other skills for students to measure. In his study, students concurred that M-reader affects their reading speed positively. In the present study, participants seem to see the biggest impact on the reading speed because it has the highest percentage among the three. As far as reading speed is concerned, the results comply with the findings in Huffman (2014), Suk (2016) and McLean and Rouault (2017). All of these studies concluded that ER is more effective than grammar-translation method in improving reading rate. Moreover, Nakanishi's (2015) and Jeon and Day's (2016) also reported on positive effects of ER on reading rate. One reason could be students' interest in the books which ultimately leads to an increment in their reading abilities in distinctive ways. The results suggest that M-reader affects students' reading speed in a tangible way.

The findings are also in line with those of Webb and Chang (2015), Suk's (2016) and McQuillan (2019) where they reported that ER affects students' vocabulary range positively but not as much as reading speed. Moreover, Nakanishi's (2015) and Jeon and Day's (2016) also reported on positive effects of ER on vocabulary which is in line with the findings of the current study. 
This is also reflected in students' comments on the advantages of M-reader. About 50 students think that vocabulary is one of the most positive points of this ER tool. On the other hand, around half the number complain about the difficulty of words in the books. As far as the first principle of Day and Bamford (2002) is concerned, ER material must be easy for the readers and having numerous hard words can decrease the motivation among the students. It is suggested that more attention be paid to the difficulty range and level of vocabulary in the material used as the cornerstone for any ER program.

Additionally, M-reader is seemingly contributing to an increase in reading comprehension among students. Some scholars (Jeon \& Day, 2016; Nakanishi, 2015) have reported the effectiveness of ER on reading comprehension. The findings in the present study are also an indication of the effect of M-reader on students' reading comprehension.

To sum up, the results imply that the students believe M-reader positively influences their reading skills including reading speed, vocabulary range and reading comprehension. It could be claimed that not only does M-reader influence students' English language ability in general, but it also has an impact on various language areas such as vocabulary range, reading speed and reading comprehension. Further research is recommended in the context of the present study targeting separate aspects of students' English reading skill.

\section{Reading in English}

The findings indicate that the students mostly credit M-reader as a good motive to continue reading in English. The results are consistent with much of the current literature (Al Damen, 2018; Cheetham et al, 2016; McBride \& Milliner, 2018; Robb, 2015). The results prove that M-reader plays a significant role in motivating students to carry on with further reading in English. This could be due to short tests (Brierley, 2009; Reed \& Goldberg, 2008) or fun (Miller, 2012). It could be inferred that M-reader inspires students to read more books in English. The students' positive attitude toward reading in itself is also reflected in the open-ended comments. This is what Day and Bamford (2002) referred to as 'Reading is its own reward' (p. 139). M-reader is apparently in line with the sixth principle of Day and Bamford. 
Rajabpour, Students' Perception of M-reader 293

\section{Tests}

The results of the study once again prove the generally controversial nature of ER quizzes. The only item about M-reader quizzes was eliminated before data analysis due to the lack of inter-reliability correlation with other variables. Nevertheless, the high number of students' comments necessitated the existence of this part. Some students saw the tests and questions as one of the advantages of M-reader. On the other hand, a bigger number of participants disapproved of the tests due to difficulty. Moreover, in the final section of the questionnaire, many comments concerned the M-reader tests or questions. Some students suggested easier and some more difficult questions in order to improve M-reader. Some of the participants asked for more diversified combination of questions.

According to Stoeckel et al. (2012), ER quizzes do not affect attitudes toward reading. Brierley (2009) reported that short tests may even provide positive motivation among the students. Reed and Goldberg (2008) said that the two-minute, five-item question test at the end of a book is not just an extrinsic motivation of students, but a representation of intrinsic motivation as some people like quizzes. On the contrary, McBride and Milliner (2018) reported concerns raised by a few students about the difficulty of the quizzes which was considered to be due lack of expertise among administrators who were learning about M-reader system settings. Another explanation was that students may have been reading books which are too difficult for them. Similarly, Campbell (2012) and Campbell and Weatherford (2013) also raised concerns about the difficulty level of the tests. Campbell (2012) stated that students in the study were reading at a level too high for them. Campbell and Weatherford (2013) found that some students needed more help in how to choose books. Same reasons may explain the bipolarity among participants' comments in the present study. In short, M-reader quizzes are a great help incorporated in this ER tool to maximize its efficiency, and is also in line with the revised principle 6 of Day and Bamford (2002, cited in Ng et al., 2019).). Nevertheless, it is suggested that M-reader developers update the question banks so that more diversified questions would probably be more helpful to the users. The findings show that students are not happy with the diversity of topics and books which is the second principle of Day and Bamford (2002). 


\section{CONCLUSIONS}

Despite the popularity of M-reader in many ELT courses around the world and specifically in Middle East, only few studies have explored how students perceive this ER tool after reaching their assigned word count. Moreover, most of these studies were not generalizable to other contexts due to different factors such as small number of participants. As a result, the present study tried to shed some light on the topic by delving into the ideas of a large number of students who had finished M-reader as a part of their English course in the Foundation Programme at Sultan Qaboos University in Oman. The results of the study clearly show that students are to a great extent in favour of M-reader in most of the aspects including the books, tests, improvement in different skills and motivation. M-reader is seemingly a great way of implementing extensive reading because it concords with most of the pre-requisites for a successful ER program. However, many students also pointed out some issues concerning the tests, the number and variety of books and the M-reader rules. They ultimately presented their ideas on how to improve M-reader where adding new books, revising the tests and running it online were the most frequent ideas they proposed. Although M-reader is following most of the principles proposed by Day and Bamford (2002), it seemingly requires few adjustments and revisions especially with the number of books, diversity of books and topics, and last but not least, the quizzes. Students' strongly positive attitude toward M-reader should not make teachers take it for granted that it is applying all its potential and is adequate. Like any other ER program, just running it with the claim that students like it and there is no need to adjust it is not acceptable. More flexibility in design, books, tests and adding new features like sound, picture or even a video can enhance several skills extensively, not only reading. Further studies can probably work on how M-reader affects students' actual performance in tests for instance tests which evaluate students' reading skill in English or tests which targets various language areas such as grammar or vocabulary. Running longitudinal studies might also generate more in-depth data about this popular online tool.

\section{REFERENCES}

Al Damen, T. M. (2018). The effectiveness of M-reader in promoting extensive reading among Arab EFL Learners. Arab World English Journal (AWEJ) 
Proceedings of 1st MEC TESOL Conference 2018, 3-23. Retrieved from https://www.researchgate.net/publication/327052629_The_Effectiveness_ of_M-reader_in_Promoting_Extensive_Reading_Among_Arab_EFL_ Learners

Al -Musalli, A. (2014). Redefining the reading culture: Overcoming EFL teachers' prejudices against students' reading habits. Arab World English Journal, 5(1), 211-223.

Al Yaaqubi, A., \& Al-Mahrooqi, R. (2013). How does reading literature for pleasure affect EFL learners? The Asian EFL Journal Professional Teaching Articles, 72, 27-46.

Allan, J. (2014). Encourage extensive reading with M-Reader| TESL Ontario Blog. Retrieved from http://blog.teslontario.org/encourage-extensivereading-withmreader/

Al-Mahrooqi, R. (2012). Reading literature in English: Challenges facing Omani college students. The Asian EFL Journal Professional Teaching Articles, 57, 24-51.

Al-Mahrooqi, R., \& Denman, C. (2016). Establishing a reading culture in Arabic and English in Oman. Arab World English Journal, 7(1), 5-17.

Anandari, C.L. \& Iswandari, Y.A. (2019). Extensive reading in Indonesian schools: A successful story. TEFLIN Journal, 30(2), 137-152.

Apple, M. T. (2005). Extensive reading and the motivation to read: A pilot study. Doshisha Studies in Language and Culture, 8(1), 193-212.

Aulia, V. (2019). Promoting extensive reading activity by constructing reading $\log$ project in EFL class. Research and Innovation in Language Learning, 2(2), 101-119.

Bell, T. (2001). Extensive reading: Speed and comprehension. The Reading Matrix, 1(1), 1-8.

Bieri, E. T. (2015). Implementing M-Reader: Reflections and reactions. Extensive Reading in Japan, 8(2), 4-7.

Boutorwick, T., Macalister, J., \& Elgort, I. (2019). Two approaches to extensive reading and their effects on L2 vocabulary development. Reading in a Foreign Language, 31(2), 150-172.

Brierley, M. (2009). Assessing extensive reading through written responses and comprehension tests. Proceedings of the 8th Annual JALT Pan-Sig Conference, 45-53. Toyo Gakuen University, Nagareyama Campu. Retrieved from http://jalt.org/pansig/2009/HTML/Brierley.htm 
Brown, D. (2012). Online support systems for extensive reading: Managing the tension between autonomy and institutional education. The Language Teacher, 36(2), 11-16.

Camiciottoli, B. C. (2001). Extensive reading in English: Habits and attitudes of a group of Italian university EFL students. Journal of Research in Reading, 24(2), 135-153.

Campbell, A. P. (2012). Implementing the Moodle Reader module. Extensive Reading World Congress Proceedings, 1, 101-104.

Campbell, J., \& Weatherford, Y. (2013). Using M-Reader to motivate students to read. In S. Miles \& M. Brierley (Eds.), Extensive Reading World Congress Proceedings, 1-12. Seoul: Extensive Reading Foundation.

Cheetham, C., Harper, A., Elliott, M., \& Ito, M. (2016). Assessing student attitudes toward Graded Readers, MReader and the MReader challenge. The Reading Matrix, 16(2), 1-19.

Creswell, J. W., \& Plano Clark, V. L. (2018). Designing and conducting mixed methods research ( $3^{\text {rd }}$ ed.). SAGE Publications.

Day, R. R., \& Bamford, J. (2002). Top ten principles for teaching extensive reading. Reading in a Foreign Language, 14(2), 136-141.

Day, R., \& Bamford, J. (1998). Extensive reading in the second language classroom. Cambridge University Press.

Geluykens, R. (2008). Cross-cultural pragmatics: Definition and methodology. In R. Geluykens \& B. Kraft (Eds.). Institutional discourse in crosscultural contexts (pp. 49-84). Lincom Europa.

Gravetter, F. J., \& Wallnau, L. B. (2008). Essentials of statistics for the behavioral sciences. Thomson/Wadsworth.

Grabe, W., \& Stoller, F. (2002). Teaching and researching reading. Reading in a Foreign Language, 14(2), 155-158.

Greenberg, D., Rodrigo, V., Berry, A., Brinck, T. \& Joseph, H. (2006). Implementation of an extensive reading program with adult learners. Adult Basic Education, 16(2), 81-97.

Greene, J. C. \& Caracelli, V. J. (1997). Defining and describing the paradigm issue in mixed-method evaluation. New Directions for Evaluation, 1997(74), 5-17.

Hair, J. F., Black, W. C., Babin, B. J., \& Anderson, R.E. (2010). Multivariate data analysis (7th ed). Pearson.

He, M. (2014). Does extensive reading promote reading speed? The Reading Matrix, 14(1), 16-25. 
Horst, M. (2005). Learning L2 vocabulary through extensive reading: A measurement study. The Canadian Modern Language Review, 61(3), 355382.

Howell, D. C. (2011). Fundamental statistics for the behavioral sciences. Wadsworth Cengage Learning.

Huffman, J. (2014). Reading rate gains during a one-semester extensive reading course. Reading in a Foreign Language, 26(2), 17-33.

Jeon, E. Y., \& Day, R. R. (2016). The effectiveness of ER on reading proficiency: A meta-analysis. Reading in a Foreign Language, 28(2), 246265.

Johnson, Y. (2012). Attitudes towards EFL learning and extensive reading in Japanese engineering students. Journal of Language and Culture of Hokkaido, 10, 65-81.

Krashen, S., Lee, S., \& Lao, C. (2018). Comprehensible and compelling: The causes and effects of free voluntary reading. Libraries Unlimited.

Kweon, S.O., \& Kim, H.-R. (2008). Beyond raw frequency: Incidental vocabulary acquisition in extensive reading. Reading in a Foreign Language, 20(2), 191-215.

Lai, E. F. K. (1993). The effect of a summer reading course on reading and writing skills. System, 21(1), 87-100.

Macalister, J. (2015). Guidelines or commandments? Reconsidering core principles in extensive reading. Reading in a Foreign Language, 27(1), 122-128.

Mason, B. \& Krashen, S. (1997). Can extensive reading help unmotivated students of EFL improve? ITL Review of Applied Linguistics, 9(2), 78-84.

McBride, P., \& Milliner, B. (2018). Introduction to M-Reader: An online extensive reading aid for schools. The English Teacher, 45(2), 96-105.

McLean, S., \& Rouault, G. (2017). The effectiveness and efficiency of extensive reading at developing reading rates. System, 70, 92-106.

McQuillan, J. (2019). Where do we get our academic vocabulary? Comparing the efficiency of direct instruction and free voluntary reading. The Reading Matrix, 19(1), 129-138.

Mermelstein, A. D. (2015). Improving EFL learners' writing through enhanced extensive reading. Reading in a Foreign Language, 27(2), 182-198.

Miles, M. B. \& Huberman, A. M. (1994). Qualitative data analysis. Sage. 
Miller, K. (2012). How we do it . . . at Tsurumi University. Extensive Reading in Japan, 5(2), 6-9. Retrieved from http://englisheveryday. weebly.com/how-we-do-it-at-tsurumi.html

Modirkhamene, S., \& Gowrki, F. (2011). Extensive reading in relation to lexical knowledge \& reading fluency: Evidence from Iranian EFL learners. Modern Journal of Language Teaching Methods, 1(3), 5-23.

Mori, S. (2015). If you build it, they will come: From a "Field of Dreams" to a more realistic view of extensive reading in an EFL context. Reading in a Foreign Language, 27(1), 129-135.

Nakanishi, T. (2015). A meta-analysis of extensive reading research. TESOL Quarterly, 49(1), 6-37.

Ng, Q. R., Renandya, W. A., \& Chong, M. W. C. (2019). Extensive reading: Theory, research and implementation. TEFLIN Journal, 30(2), 171-186.

Park, J. (2016). Integrating reading and writing through extensive reading. ELT Journal, 70(3), 287-295.

Pigada, M., \& Schmitt, N. (2006). Vocabulary acquisition from extensive reading: A case study. Reading in a Foreign Language, 18(1), 1-28.

Reed, K. \& Goldberg, P. (2008). Integrating quizzes with extensive reading. Presentation at the 34th Annual JALT International Conference. National Olympics Memorial Youth Center.

Renandya, W. A. (2007). The power of extensive reading. RELC Journal, 38(2), 133-149.

Renandya, W.A., Sundara Rajan, B. R., \& Jacobs, G. M. (1999). Extensive reading with adult learners of English as a second language. RELC Journal, 30(1), 39-60.

Robb, T. \& Kano, M. (2013). Effective extensive reading outside the classroom: A large-scale experiment. Reading in a Foreign Language, 25(2), 234-247.

Robb, T. \& Susser, B. (1989). Extensive reading vs. skills building in an EFL context. Reading in a Foreign Language, 5(2), 239-251.

Robb, T. (2002). Extensive reading in an Asian context: An alternative view. Reading in a Foreign Language, 14(2), 146-147.

Robb, T. (2009). The reader quiz module for extensive reading. In M. Thomas (Ed.), Selected proceedings of the thirteenth annual JALT CALL SIG Conference 2008, 109-116. Tokyo: Japan Association for Language Teaching. 
Ryan, G. W., \& Bernard, H. R. (2003). Techniques to identify themes. Field Methods, 15(1), 85-109.

Shen, M.Y. (2008). EFL learners' responses to extensive reading: Survey and pedagogical application. The Reading Matrix, 8(2), 111-123.

Sheu, S. P-H. (2003). Extensive reading with EFL learners at beginning level. TESL Reporter, 36(2), 8-26.

Stewart, D. (2014). ER with online graded readers. Extensive Reading in Japan, 7(2), 16-18.

Stoeckel, T., Reagan, N., \& Hann, F. (2012). Extensive reading quizzes and reading attitudes. TESOL Quarterly, 46(1), 187-198.

Suk, N. (2016). The effects of extensive reading on reading comprehension, reading rate, and vocabulary acquisition. Reading Research Quarterly, 52(1), 73-89.

Taguchi, E., Takayasu-Maass, M., \& Gorsuch, G. J. (2004). Developing reading fluency in EFL: How assisted repeated reading and extensive reading affect fluency development. Reading in a Foreign Language, 16(2), 70-96.

Takase, A. (2007). Japanese high school students' motivation for extensive L2 reading. Reading in a Foreign Language, 19(1), 1-18.

Tanaka, H. \& Stapleton, P. (2007). Increasing reading input in Japanese high school EFL classrooms: An empirical study exploring the efficacy of extensive reading. The Reading Matrix, 7(1), 115-131.

Tran, A. (2006). Modified extensive reading for English-language learners. Reading Improvement, 43(4), 173-178.

Waring, R., \& McLean, S. (2015). Exploration of core and variable dimensions of extensive reading research and pedagogy. Reading in a Foreign Language, 27(1), 160-167.

Webb, S., \& Chang, A. (2015). Second language vocabulary learning through extensive reading with audio support: How do frequency and distribution of occurrence affect learning? Language Teaching Research, 19(6), 667686.

Wigfield, A. (1994). Expectancy-value theory of achievement motivation: A developmental perspective. Educational Psychology Review, 6, 49-78.

Wigfield, A., \& Eccles, J. (2000). Expectancy-value theory of achievement motivation. Contemporary Educational Psychology, 25, 68-81.

Yamini, M. \& Rahimi, M. (2007). A guide to statistics and SPSS for research in TEFL, linguistics and related disciplines. Koshamehr. 
300 TEFLIN Journal, Volume 31, Number 2, July 2020

\section{APPENDIX}

\section{Questionnaire}

\section{Students' Questionnaire}

This questionnaire is designed to investigate your perceptions about the M-reader. Your answers to the questionnaire will be kept confidential and used only for research purposes. Read the statements below carefully. Rate them from strongly disagree to strongly agree. Put a tick $(\sqrt{ })$ in the box which best reflects your perception.

تم تصميم هذا الاستبيان لاستكثـاف ار اءك حول MReader. سيتم الاحتفاظ بإجاباتك وسيتم استخدامها فقط لأغر اض البحث. اقر اء البيانات أدناه بعناية. قيّمها من لا أو افق بشدة الى أن أن أو افق بشدة. ضع علامة (ل) في المربع الذي يعكس أفضل راى للك.

\begin{tabular}{|c|c|c|c|c|c|}
\hline \multicolumn{6}{|c|}{ Gender: } \\
\hline & & 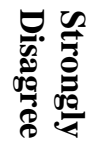 & 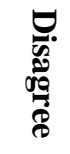 & $\underset{8}{8}$ & 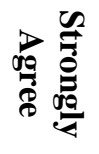 \\
\hline 1 & $\begin{array}{l}\text { I enjoyed reading Graded books on M- } \\
\text { reader. } \\
\text { لقد استمتعت بقر اءة الكتب على ريدر إمتر }\end{array}$ & & & & \\
\hline 2 & $\begin{array}{l}\text { M-reader helped me improve my } \\
\text { English skills. } \\
\text { ساعدني ام ريدر في تحسين مهار آلإنجليزية } \\
\text { اللغيز }\end{array}$ & & & & \\
\hline 3 & 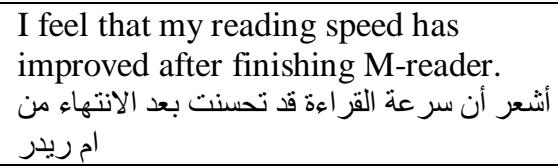 & & & & \\
\hline 4 & $\begin{array}{l}\text { I feel that my vocabulary has } \\
\text { increased. } \\
\text { أشعر أن مفرداتي زادت }\end{array}$ & & & & \\
\hline 5 & 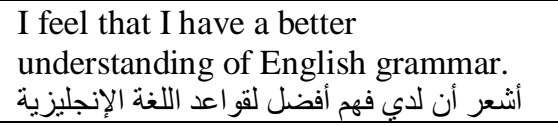 & & & & \\
\hline
\end{tabular}


Rajabpour, Students' Perception of M-reader 301

\begin{tabular}{|c|c|c|c|c|c|}
\hline & & 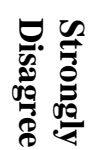 & 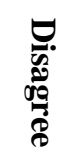 & $\underset{8}{8}$ & 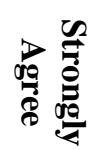 \\
\hline 6 & $\begin{array}{l}\text { I think reading in English is important. } \\
\text { أعتقد أن القزة باللغة الإنجيزة مهمة }\end{array}$ & & & & \\
\hline 7 & $\begin{array}{l}\text { I found the M-reader quizzes } \\
\text { challenging. } \\
\text { لقد وجدت الإختبارات القصبرة لام ريدرصعبة }\end{array}$ & & & & \\
\hline 8 & 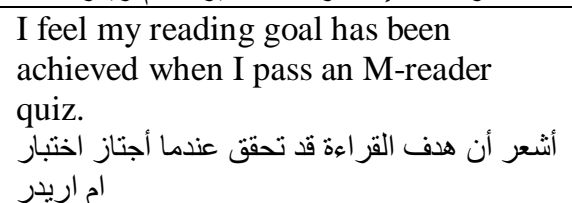 & & & & \\
\hline 9 & $\begin{array}{l}\text { M-reader encouraged me to read more } \\
\text { English books. } \\
\text { شجعني ام ريدر على قر اءة المزيد من الكتبزية. } \\
\text { الإنجليزية }\end{array}$ & & & & \\
\hline 10 & 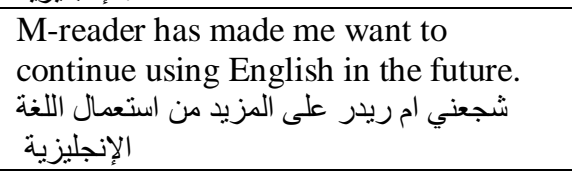 & & & & \\
\hline
\end{tabular}

Do you like M-reader?

هل تحب ام ريدر؟

If yes, what did you like the most about M-reader?

اذا نعم ما الذي أعجبك أكثر في ام ريدر؟

What are some problems of M-reader?

ما هي بعض مشاكل ام ريدر؟

How can we improve this system?

كيف يمكن ان نحسّن آم ريدر؟ 